\title{
Teachers' Access to and Use of ICT: An Indicator of Growing Inequity in Swedish Schools
}

\author{
Elin Thunman \\ Uppsala University, Sweden \\ Marcus Persson \\ Örebro University, Sweden
}

\begin{abstract}
In light of how the knowledge society may give rise to new forms of inequity in schools, the purpose of this article is to examine the stratification of Swedish schoolteachers' access to and use of ICT. The empirical data consist of a nationwide survey conducted in 2010, involving 6000 Swedish teachers in all grades (except pre-school and university). Accounting for teachers' age, gender, grade, and principal organization, bivariate analyses were conducted. The study finds significant differences between teacher's age and principal organization, indicating a growing gap between teachers in public versus independent schools. The finding is discussed in relation to the current research and its potential consequences for equitable learning activities.
\end{abstract}

Keywords: Teachers; ICT; Sweden; Knowledge society; Equity

\section{Introduction}

According to the work of Manuel Castells (2000), the society of the 21st century will be a 'network society'. A fundamental feature of the social structure in the information age is its reliance on networks as the key feature of social morphology. Or as Ashwin Kumar (2012) puts it: computers and Internet are the backbone of knowledge societies and they are a major factor in changing human behavior and social relationships. While networks are forms of social organizations, they are now empowered by new information and communication technologies so that they become able to cope at the same time with flexible decentralization and focused decision-making. Closely related to the notion of the socio-technical understanding of the network society, is the socioeconomical understanding of the notion of the 'knowledge society' (Machlup, 1962; Bell, 1976; Kodama, 2007; Sörlin \& Vessuri, 2007; Berisha-Namani \& Badivuku-Pantina, 2009).

By the turn of the century, humanity had learned how to mass-produce knowledge. This new skill had been invented in the environment of private business enterprise and market economy. However, it is generic in nature. It combines the capacities of modern ICT with information and group thinking organized in shared spaces (virtual and physical) for knowledge creation. In many economies knowledge has replaced industrial organization and production as the major source of 
productivity. This has caused increased interest in knowledge as a factor for growth and development, coined the term 'knowledge economy' or 'knowledge society' and bestowed it on countries with economies featuring a relatively large and growing service sector or on economies in which manipulation of information and creation of knowledge replace industrial production as the main contributor to GDP (Kahin \& Foray, 2006). In a knowledge society, the agricultural and manufacturing sectors become less significant, in favor of service and knowledge-based industries (UN 2005).

Because the knowledge society is based on the network society, which, in turn, is based on communication networks, that transcend boundaries, the knowledge society is much more globalized than industrial society has ever been. With enterprises being exposed to global competition and global markets competition becoming greater, cooperation is an important strategy for organizations and enterprises as well as for individuals. In the new setup of knowledge societies where operations are expected to transcend the economic rationality of efficiency and effectiveness, a commercialization and marketization of public institutions and a commoditization of knowledge will follow (Rahaman, 2003).

The school is a natural key resource in the development of the knowledge society - as a producer of skills necessary for the future work force - and as such, the school itself becomes an important object of change. ICT becomes a vital tool on which the mass-producing of new meanings is dependent. A knowledge society requires, among other things, that citizens, in general, and a productive work force, in particular, are able to use information critically and ethically, generate new knowledge and ideas, and, based on these, produce innovations. The societal transformation towards a knowledge society leads to fundamental implications for the individual (teacher and students) as well as the school organization, as explained by Castells and Cardoso (2005, p.18):

At the source of the entire process of social change there is a new kind of worker, the selfprogrammable worker, and a new type of personality, the values-rooted, flexible personality able to adapt to changing cultural models along the life cycle because of her/his ability to bend without breaking, to remain inner-directed while evolving with the surrounding society. This innovative production of human beings, under the conditions of the crisis of patriarchalism and the crisis of the traditional family, requires a total overhauling of the school system, in all its levels and domains. This refers certainly to new forms of technology and pedagogy, but also to the content and organization of the learning process.

In this light, several scholars have put forth the new requirements, for teachers as well as for students, in the knowledge society school. For example, Sahlberg (2006) advocates that teaching for the knowledge society requires developing broad cognitive learning, collaborative processes, risk-taking, creativity, and innovation in schools and classrooms. Teaching in and for the knowledge society, as Hargreaves (2003, p.29) notes, is concerned with sophisticated cognitive learning and:

an expanding and changing repertoire of research-informed teaching practices, continuous professional learning and self-monitoring, teamwork, learning partnerships with parents, developing and using collective intelligence, and cultivating a profession that 
values problem-solving, risk-taking, professional trust, coping with change and committing to continuous improvement.

Knowledge society should not be understood as an epithet that any single country can achieve or not; instead all countries are knowledge societies to different degrees. In an attempt to rank a random sample of 45 countries according to an index of knowledge societies, based on three structural measures: assets, advancements, and foresightedness, the UN (2005) ranked Sweden at the very top of the list - a country with the best pre-requisitions for cultivating a knowledge society.

A more concrete aspect of Sweden as a growing knowledge society is discussed in a recent study by Lundström and Parding (2011) about the individualistic practice of school choice. As many other Western countries, the Swedish education system is currently undergoing major restructuring, and school choice reform has been introduced even though education in Sweden has traditionally been a public issue and students have by default been enrolled in the (municipal) school in the area where they live. During the 1990s, the state promoted school choice and competition through legislation and funding of independent (private) schools (Government Bill, 1991/1992; 1992/1993). During the 20 years that the reform has been active the expansion of upper secondary independent schools has been significant, from attracting 2 percent of all students in Sweden to attracting 22 percent. This demonstrates the competing aspect of the knowledge society, i.e. not only individualistic competition amongst the teacher and student groups, but now also between schools in order to enhance their value on the educational market, thereby attracting the most qualified work force and the top students.

From a sociological perspective, the rise of the knowledge society has been accused of contributing to the stratification of society from both within nations and between nations (Reich, 1991; Kofman, 2007; Kumar, 2012). At the global level, this could further strengthen those who presently control knowledge and to that extent bring a cleavage between the rich and poor nations. Within a nation, the gap between the rich who can afford the Internet and the poor who do not have access even to a telephone line is also likely to widen according to Kumar (2012). Stratification is not only about those with and without access to ICT - i.e. the digital divide - but also about those with and without knowledge of how to maximize the use and get the most out of ICT - i.e. the knowledge gap (Tichenor et al, 1970).

An equitable school system means in essence that all students irrespective of their social and financial background have the same opportunities to achieve learning goals in school. PISA 2000 demonstrated that Sweden occupied a strong position as regards equity. An analysis of the results in PISA 2009 shows that Sweden has lost its leading position, and currently performs no better than average countries. Between year 2000 and 2009, the differences between high and low performing students have increased, as well as the differences between high and low performing schools. In addition, a student's socio-economic background has become more important in determining performance, and is now more important in Sweden compared to other OECD countries (OECD, 2011). The Swedish National Agency for Education (2009c, 2010a, 2010b, 2012, 2013), has put forth several structural observations that point to a growing inequity in Swedish schools: 
(a) Increased freedom to choose school;

(b) Increased segregation in society;

(c) Increased individualization in education, students must take greater responsibility of their learning through self-directed schoolwork;

(d) Shifting responsibilities from teacher to student and from school to family;

(e) Increased digitalization of the school, for instance through growing computer access for students.

In this paper we draw attention to an additional tendency - the stratification of teachers in relation to ICT access and usage.

Much previous research into the use of information and communication technology (ICT) in school has focused on the role of technology and its impact on educational benefits and learning processes (Knowledge Foundation, 2006; New Media Consortium, 2010; OECD, 2010; Ramböll, 2006; Swedish National Agency for Education, 2007), and on the media habits of young people inside and outside school (Swedish Media Council 2010a, 2010b; World Internet Institute, 2009). By focusing on teachers' ICT habits, the aim of present article is to contribute to the collected body of knowledge of the role and impact of ICT in formal education.

By drawing on the findings of an unpublished national study conducted by The Swedish Educational Broadcasting Company (Utbildningsradion) in cooperation with Statistic Sweden, which provides detailed information about teachers' use of technological devices, and about the various audio and visual materials used with the help of these devices, we examine the stratification of Swedish teachers ICT use per age, gender, grade, and principal organizer.

In the following we first present the research design of the Swedish Educational Broadcasting Company study. In the succeeding two empirical sections, we present the frequency of teachers' usage of technological devices in class, and then the different ways teachers make use of these devices. Finally, we use the empirical results as a basis for discussing ICT use in relation to teacher age and principal organizer, and suggest that access to and usage of ICT can be considered playing an active part in the process of the growing inequity in Swedish schools.

\section{Research Design}

Since the mid-1980s, the Swedish Educational Broadcasting Company has studied the ICT use and media habits of Swedish teachers by means of a biannual quantitative survey. The scope of this study has changed somewhat over the years, depending on the strategic focus of the company at the time and on particular trends in the educational system and teachers' work life. Although the Swedish Educational Broadcasting Company study is one of the largest recurring studies of Swedish teachers' media habits, it has so far been for internal company use and the results have never been published before. The study from the 2009-2010 academic year was conducted by project manager Marcus Persson (former evaluator at the company's strategic unit) and project assistant Elin Thunman in collaboration with Statistics Sweden (SCB). Statistics Sweden was consulted when designing the questionnaire and has been in charge of its distribution and the data collection. 
The questionnaire consisted of 34 numbered question, with both closed and open-ended questions. The first part of the questionnaire posed demographical and background questions; then followed questions about the respondents' preferences and habits using different technical devices for audio and video material in different settings and purposes. In reply to the general aim of the study, the following questions from the survey were selected for further analysis: A) Teachers' access to different technological devices usually used in class (CD/tape player, Radio, Computer, VHS/DVD player, TV, Digital whiteboard); and B) Teachers' use of audio-visual material in class (Convey facts and information, Basis for discussion, Basis for pupils' own exercises). Using bivariate analysis, the answers to these questions were analyzed in connection to the variables: Age (in 10-year intervals), Gender (female and male), grade (0-6, 7-9, upper secondary, and adult education), and Principal organizer (independent and public school), according to the logic presented in the analytical model in Table 1.

Table 1. Analytical model

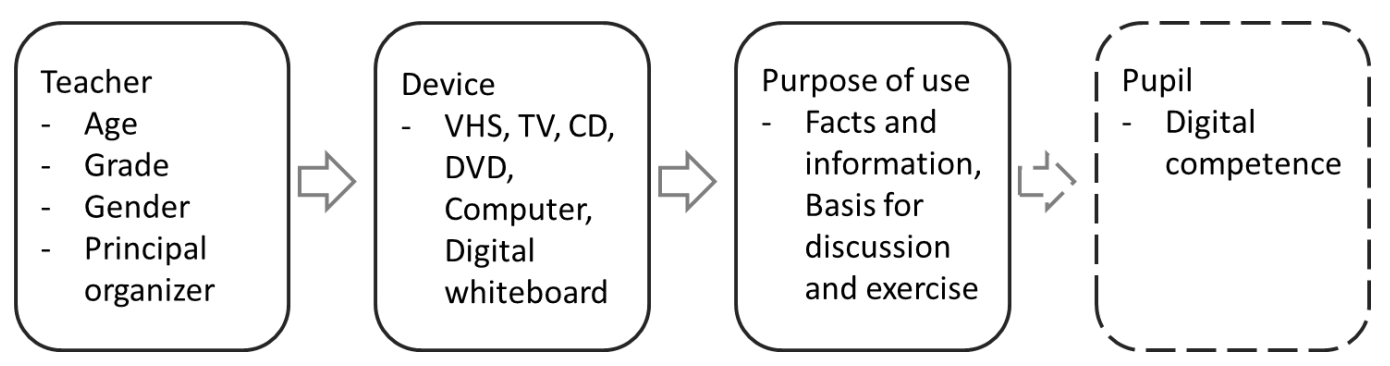

A stratified random sample of 6000 teachers was selected through Statistic Sweden's register of active educational personnel in Sweden: 1500 in primary schools, 1500 in lower secondary schools, 1500 in upper secondary schools, and 1500 in adult education. The sample was stratified in terms of gender and age for teachers in primary school (grades 0-6); gender, age, and principal organizer for teachers in lower secondary school (grades 7-9) and upper secondary school; and gender, age, and region for teachers in adult education. The questionnaire was sent to the 6000 teachers, with three notices reminding respondents to complete the survey, two of these accompanied with an additional copy of the survey. The final and total number of respondents was 3800 , which is equivalent to a response rate of 63 percent. Statistic Sweden has controlled the collected the data for missing and invalid answers, as well as weighting the data to compensate for variances between groups of teachers. The survey was administered between $12 \mathrm{March}$ and 10 May 2010, and the completed report (Persson \& Thunman, 2010) was presented to the board of the Swedish Educational Broadcasting Company in October the same year. The authors have carried out all data analyses using SPSS for windows version 21.0. The tables presented in this article are not extracted from the Swedish Educational Broadcasting Company's report, but were constructed by the authors from the original data.

\section{Findings I: Technological Devices Used for Audio- and Visual Material}

The Swedish National Agency for Education (2009a) has published a report about the access to and use of ICT and the digital competence of teachers and pupils in the Swedish educational 
system, from preschool to adult education. Their overall conclusion was that all teachers in Swedish schools have access, more or less, to computers. This access, however, is not always personal, and many teachers share a computer with colleagues. In compulsory school (i.e. grades 0-9), three of four teachers state that they share a computer with colleagues, meaning that only one of four has sole access to a personal computer at work. The level of access is significantly higher in upper secondary school, where the situation is the reverse: three of four teachers have access to a personal work computer and only one of four shares a computer (Swedish National Agency for Education, 2009a, p.7).

Regarding the actual use of technology, the Swedish National Agency for Education (2009a, p.20) states that about half of compulsory and upper secondary school teachers use computers in class every week. Only one of five compulsory schoolteachers and one of four upper secondary school teachers uses computers on a daily basis. In adult education 70 percent of teachers' state that they use computers in class every week and 43 percent use them daily.

Against this background, we present some of the main findings from the study of the Swedish Educational Broadcasting Company, which complements the data from the Swedish National Agency for Education. We begin by looking at the teachers' general use of technological devices, first for presenting visual material in class and then for presenting audio material. The reason for breaking down the data in this way is to get a firm understanding on how, and for what kind of materials, teachers use technological devices. Devices are seldom used for the sake of their own; they are used in order to deploy some specific educational material or task. Fully aware that teachers use other kind of, more traditional, educational material (such as text material), we measure teachers' use of visual and audio material in class in order to methodologically and empirically contribute to a deeper understanding of teachers' use of ICT.

The use of technological devices for presenting visual material in class is presented in detail in Table 2. We find that 56 percent of all teachers used VHS/DVD at some time during the 2009-2010 academic year. Only 22 percent used TV, while 63 percent used computers (with or without digital projectors). A fairly new device for educational purposes is the digital whiteboard, which 11 percent of all teachers use.

It should be noted that the Swedish National Agency for Education presents no information about the relationship between ICT use and teacher age and gender. Our study contributes with such data. More than half of teachers in all grades use VHS/DVD players in class to present visual material. Female teachers tend to use VHS/DVD players more often than male teachers. About 1 in 5 of all teachers uses TV in class. Examining the use of computers to present visual material in class reveals greater variation. Male teachers are inclined to use computers in class slightly more than their female colleagues. The most obvious difference in computer use, however, depends on teacher age, younger teachers using computers the most and senior teachers the least. Teachers in upper secondary school and adult education most frequently use computers to present visual material in class.

The inventory of teacher ICT access conducted by the Swedish National Agency for Education (2009a, p.11f) demonstrated that approximately 2 of 10 teachers in all grades have access to digital whiteboards; the study reveals nothing about teachers' specific use of these whiteboards. 
The Swedish Educational Broadcasting Company's study, however, indicates that these devices are used the most in the lowest grades. As with computers, the use of digital whiteboards is correlated with age: the younger the teacher, the more digital whiteboards are used.

Table 2. Technological Devices Usually Used to Present Visual Material in Class (in Percent)

\begin{tabular}{|c|c|c|c|c|c|}
\hline & & $\begin{array}{l}\text { VHS/DVD } \\
\text { player }\end{array}$ & TV & $\begin{array}{l}\text { Computer/ } \\
\text { digital projector }\end{array}$ & $\begin{array}{l}\text { Digital } \\
\text { whiteboard }\end{array}$ \\
\hline \multirow[t]{4}{*}{ Teaching grade } & $0-6$ & 52.4 & 20.6 & 48.6 & 17.3 \\
\hline & $7-9$ & 60.9 & 25.3 & 60.1 & 11.0 \\
\hline & Upper secondary & 52.3 & 18.6 & 76.2 & 6.6 \\
\hline & Adult & 57.5 & 21.9 & 66.8 & 7.8 \\
\hline \multirow[t]{4}{*}{ Teacher age } & $25-35$ & 50.3 & 19.3 & 71.2 & 13.5 \\
\hline & $36-45$ & 55.3 & 19.8 & 69.3 & 12.1 \\
\hline & $46-55$ & 57.2 & 20.6 & 61.1 & 11.1 \\
\hline & $56-63$ & 58.8 & 25.6 & 51.9 & 7.4 \\
\hline \multirow[t]{2}{*}{ Teacher gender } & Female & 61.4 & 23.8 & 59.6 & 9.9 \\
\hline & Male & 47.4 & 18.4 & 67.1 & 12.1 \\
\hline \multirow{2}{*}{$\begin{array}{l}\text { Principal } \\
\text { organizer }\end{array}$} & Public & 51.8 & 19.8 & 54.4 & 11.2 \\
\hline & Independent & 45.4 & 19.2 & 63.8 & 6.3 \\
\hline
\end{tabular}

Looking at the use according to principal organizer, the study reveals a significantly higher use of computers and digital projectors by teachers in independent schools. We return to this finding later on.

Concerning teachers' general use of technological devices to present audio material in class, we note that 65 percent of all teachers employed CD/tape players at some time during the 2009-2010 academic year. Only 7 percent used radio, while 55 percent used computers. The use of technological devices to present audio material in class is presented in detail in Table 3.

$\mathrm{CD}$ and tape players are the most commonly used technological devices in primary school and lower secondary school. Regarding age and sex, senior and female teachers most frequently use these devices. It should be noted that the results concerning the use of radio are not reliable due to the low number of observations. The low amount indicates that radio no longer is a standard device at schools.

The findings about the use of computers to present audio material goes hand in hand how various teacher groups use computers to present visual material in class, i.e. they are most heavily used by younger teachers and by upper secondary and adult education teachers. Furthermore, male teachers are slightly more likely to use computers to present audio material than their female colleagues. 
Table 3. Technological Devices Usually Used to Present Audio Material in Class (in Percent)

\begin{tabular}{|l|l|l|l|l|}
\hline & & $\begin{array}{l}\text { CD/tape } \\
\text { player }\end{array}$ & Radio & Computer \\
\hline Teaching grade & $0-6$ & 74.7 & 9.1 & 41.5 \\
\hline & $7-9$ & 71.1 & 6.5 & 51.8 \\
\hline & Upper secondary & 52.8 & 5.2 & 70.1 \\
\hline & Adult & 53.4 & 6.0 & 64.7 \\
\hline Teacher age & $25-35$ & 59.0 & 6.4 & 59.5 \\
\hline & $36-45$ & 60.3 & 6.7 & 60.3 \\
\hline & $46-55$ & 67.8 & 7.0 & 53.2 \\
\hline & $56-63$ & 70.4 & 7.5 & 48.9 \\
\hline Teacher gender & Female & 67.9 & 6.9 & 53.2 \\
\hline & Male & 58.8 & 7.1 & 58.7 \\
\hline Principal organizer & Public & 32.8 & 3.7 & 24.6 \\
\hline & Independent & 27.4 & 2.3 & 34.3 \\
\hline
\end{tabular}

Finally, the use of technological devices to present audio material per principal organizer follows the same pattern as previously shown according to visual material, namely, the use of computers is significantly higher among teachers in independent schools. The Swedish National Agency for Education (2009a, p.8f) has suggested that independent schools generally provide better access to computers than public schools. This is evident in the ratio of students to computers, which is $4.5: 1$ in independent versus 6.0:1 in public compulsory schools, and 1.6:1 in independent versus 2.5:1 in public upper secondary schools, according to the agency's study. Regarding teacher access to computers in independent versus public schools, the Swedish National Agency for Education report differences between grades; the largest variations are documented in upper secondary schools, where 65 percent of teachers in independent schools report that they "always" have access to a computer in class, compared to 46 percent of public school teachers. In this way, our study complements and validates the study of the Swedish National Agency for Education, and thus the gap between public and independent teachers' use of ICT can be affirmed.

Several reports characterize Swedish schools as undergoing a digital transformation since the beginning of the 1990s. For example, there has been a development from 38 pupils per computer in compulsory school in 1993 to six in 2009; and from 11 pupils per computer in upper secondary school in 1993 to 1.6 in 2009 (Broady, 2000; Swedish National Agency for Education, 2009a). However, digital devices include more than computers. Summarizing our findings, we see that, alongside computers, VHS and DVD players are frequently used to present visual material. Comparing the limited use of TVs and the greater use of computers reported by teachers, one probable conclusion is that DVD players are more frequently used than VHS players. While a DVD can be played on a computer, a VHS tape needs its own player and a TV. In terms of use of ICT to present audio material, the radio is obviously obsolete. Today, teachers use CD and tape players or computers to present audio material. Although digital whiteboards are new devices in Swedish schools, our results indicate that these devices are already becoming popular among teachers in lower grades and among younger teachers. Our findings confirm the belief that Swedish schools 
are undergoing a digital transformation, and our material suggests that the younger teachers and the independent schools play a vital part in this development.

\section{Findings II: Digital Literacy and the Use of Audio- and Visual Material}

Simply diffusing the Internet or putting more computers in the schools will not in it, according to the logic of Castells and Cardoso $(2005$, p.6), amount to much social change. Instead it is important to understand how ICT is used since it is the different teaching practices of the technologies that change learning. In this second empirical section we will focus on how Swedish teachers make use of ICT. The Swedish Educational Broadcasting Company study provides one possible answer based on the question if the teacher usually use audio and video material to 'convey facts and information', as 'basis for discussion' or 'for pupils' own exercises'. This question might be related to the notion of 'digital literacy', understood as the sum of simple ICT skills (read, write and calculate), and more advanced skills that make creative and critical use of digital tools and media possible. ICT skills consist of being able to use software, to search, locate, transform and control information from different digital sources, while the critical and creative ability also imply a capacity to evaluate, use sources of information critically, interpret and analyze digital genres and media forms (Erstad, 2006). In the following, we primarily categorize the use of audio and video material to 'convey facts and information' as simple ICT skills while the use of audio and video material as 'basis for discussion' and 'for pupils' own exercises' are labeled as advanced skills.

Not surprisingly, in the Swedish Educational Broadcasting Company study, almost all teachers (92 percent) in all grades occasionally used visual material, with the aid of VHS and DVD players and computers. No significant differences in visual material use between groups can be detected; though the educational purposes for which teachers use visual material in class do differ (Table 4).

Table 4. How Teachers Usually Use Visual Material in Class (in Percent)

\begin{tabular}{|c|c|c|c|c|}
\hline & & $\begin{array}{l}\text { Convey facts and } \\
\text { information }\end{array}$ & $\begin{array}{l}\text { Basis for } \\
\text { discussion }\end{array}$ & $\begin{array}{l}\text { Basis for pupils' } \\
\text { own exercises }\end{array}$ \\
\hline \multirow[t]{4}{*}{ Teaching grade } & $0-6$ & 95.1 & 45.8 & 19.7 \\
\hline & $7-9$ & 87.4 & 66.1 & 31.4 \\
\hline & Upper secondary & 86.0 & 68.3 & 39.7 \\
\hline & Adult & 85.2 & 67.0 & 30.4 \\
\hline \multirow[t]{4}{*}{ Teacher age } & $25-35$ & 88.2 & 66.8 & 38.9 \\
\hline & $36-45$ & 88.3 & 67.0 & 32.8 \\
\hline & $46-55$ & 88.5 & 62.9 & 31.4 \\
\hline & $56-63$ & 89.1 & 51.4 & 19.9 \\
\hline \multirow[t]{2}{*}{ Teacher gender } & Female & 87.8 & 64.5 & 31.4 \\
\hline & Male & 89.6 & 57.3 & 28.4 \\
\hline \multirow[t]{2}{*}{ Principal organizer } & Public & 81.7 & 54.2 & 25.3 \\
\hline & Independent & 73.3 & 59.3 & 33.6 \\
\hline
\end{tabular}


We note that 89 percent of all teachers use the material to convey facts and information, 62 percent use it as a basis for discussions, and 30 percent use it as a basis for the pupils' own exercises. The differences in how primary school (grade 0-6) teachers use visual material in comparison with the other teacher groups are obvious. Primary school teachers are the ones who most commonly use visual material to convey facts and information and most seldom use them as a basis for discussion or for pupils' own exercises.

In the table above it also evident that senior teachers use visual material as a basis for discussions and for pupils' own exercises less often than their younger colleagues do. Though the differences are small, it seems that male teachers are less inclined than female teachers to use visual material as a basis for discussions and for pupils' own exercises. We observe that teachers in independent schools use visual material in class with greater variety than public school teachers, who are more prone to use visual material to convey facts and information.

Even though audio material is less frequently used in class than visual material, still half of all teachers (50 percent) used audio material in class at some time during the 2009-2010 academic year. Compared with the use of visual material, the use of audio material varies more between teacher groups. The use of audio material is the greatest among teachers in the lowest grades and is progressively less used at higher educational levels. Audio material is more frequently used by younger teachers, and by female teachers. These statistics are presented in greater detail in Table 5 below.

Table 5. How Teachers Usually Use Audio Material in Class (in Percent)

\begin{tabular}{|l|l|l|l|l|}
\hline & & $\begin{array}{l}\text { Convey facts } \\
\text { and information }\end{array}$ & $\begin{array}{l}\text { Basis for } \\
\text { discussion }\end{array}$ & $\begin{array}{l}\text { Basis for pupils' own } \\
\text { exercises }\end{array}$ \\
\hline Teaching grade & $0-6$ & 71.6 & 29.7 & 41.0 \\
\hline & $7-9$ & 64.3 & 52.4 & 47.2 \\
\hline & Upper secondary & 67.9 & 58.6 & 45.4 \\
\hline & Adult & 70.9 & 54.1 & 39.5 \\
\hline Teacher age & $25-35$ & 59.6 & 45.8 & 55.6 \\
\hline & $36-45$ & 65.9 & 49.9 & 45.0 \\
\hline & $46-55$ & 73.1 & 48.3 & 43.6 \\
\hline & $56-63$ & 74.8 & 43.5 & 31.5 \\
\hline Teacher gender & Female & 66.5 & 48.3 & 42.2 \\
\hline & Male & 72.9 & 43.7 & 45.3 \\
\hline Principal organizer & Public & 34.1 & 20.7 & 19.5 \\
\hline & Independent & 29.9 & 28.4 & 25.4 \\
\hline
\end{tabular}

As with visual material, teachers in primary school (grades 0-6) use audio material mainly to convey facts and information and less as a basis for discussion or for pupils' own exercises. In 
addition, in line with the teaching practice pattern regarding use of visual material, senior teachers use audio material primarily to convey facts and information. It is the youngest teachers who are most inclined to use audio material as a basis for pupils' own exercises and least inclined to use it to convey facts and information. Regarding gender differences, more male teachers use audio material to convey facts and information than do their female colleagues. The differences between how teachers in independent and public schools use audio material are exactly the same as with visual material: teachers in independent schools use the material as a basis for discussion and pupils' own exercises significantly more often than public school teachers.

In sum, the study indicates that younger and independent schoolteachers are more prone than senior teachers to use computers for both audio and visual materials. They also seem more inclined to use ICT in activities to promote student discussion and for pupils' own exercises instead of merely to communicate content. In other words, younger teachers and independent schoolteachers seem to use ICT to a larger extent, more interactively, activity-oriented and more varied than senior teachers and public school teachers. The results could be understood in line with the notion of digital literacy, i.e. the sum of simple and advanced ways of making use of ICT. The outcome of the study suggests that the younger teachers and independent school teachers might be ascribed a higher digital literacy since these teacher groups are more inclined to combine simple (to use of audio and video material to 'convey facts and information') and advanced (to use of audio and video material as 'basis for discussion' and 'for pupils' own exercises') ways of making use of ICT. These findings go hand in hand with what several researchers have called "teaching for a knowledge society", for example, by emphasizing self-directed work and collaboration (Hargreaves, 2003; Sahlberg \& Boce, 2010; Sörensen, Danielsen \& Nielsen, 2006; Trilling \& Hood, 1999). Scholars also point out that "teaching for a knowledge society" poses new challenges and makes greater demands of teachers' ICT skills (Cartelli et al., 2006; UNESCO, 2011).

The Swedish National Agency for Education (2009b, p.11f) show that the differences in computer access between independent and public school pupils have increased somewhat in recent years, though the agency has not noticed any major differences in teacher access to computers depending on principal organizer. Our findings complement those of the Swedish National Agency for Education study in that we measure actual teacher use of ICT rather than simply their access. By doing this, our study shows that younger teachers and teachers in independent schools use ICT to a greater extent, in line with the notion of teaching in a knowledge society.

Because of the methodological limitations of the Swedish Educational Broadcasting Company study we have examined a mere fracture of what digital literacy mean in practice. More research about teachers' dissimilar digital literacy should be implemented to add to the knowledge about the structural implications for inequitable learning conditions at Swedish schools.

\section{Discussion}

The notion of a digital divide has been debated in the past decade. The discussion has considered the reasons for and consequences of the gap between those who have access to ICT and those who have not, and of the gap between those with greater knowledge of how to use ICT and those with less (Hargittai, 2003; OECD, 2001; Warschauer, 2003). Regarding ICT in relation to schools and 
education, it is usually students' unequal opportunities that are discussed (OECD, 2007, 2010). The findings from the Swedish Educational Broadcasting Company study raise another, less recognized aspect of the digital divide, namely teachers' different opportunities regarding both access to and use of ICT (cp. Epstein, Nisbet \& Gillespie, 2011). We found that young teachers, in all grades, and teachers in independent schools make most use of digital tools in class.

Regarding the age of the teacher, similar results have been identified in a European benchmarking study (Korte \& Hüsing, 2006), documenting access and use of ICT among 27 European member states. Depending on the country and type of school, the study identifies highly different levels of competence and skills among teachers for using computers in class. The study emphasizes the correlation between teachers' use of ICT and teachers' age. Greatest motivation to use ICT in class is found among the youngest teachers. A later study of digital differences between groups of teachers in North Cyprus (Uzunboylu \& Tuncan, 2010) confirms this correlation. Thus, Swedish teachers' ICT usage reflects the age-related pattern of European teachers' use in general. Our study confirms the image conveyed by the European research about the young teachers' higher levels of ICT competence. One possible explanation of these age differences might be that the younger teachers, as 'digital natives', often already during childhood have become accustomed to use computers and other digital tools as an integrated part of everyday life (Prensky, 2001).

The fact that younger teachers in general possess more ICT skills is not unexpected, and need not necessary be treated as a structural problem; it could be seen as a generational dilemma that probably will adjust itself over time. Following the theoretical logic of the knowledge society, as outlined above, we should however be observant of the younger teachers in their capacity of employed by the independent schools. As shown above, in our study it was found that not just the age gap but also an ICT access gap were the two most important variables explaining differences in teachers' e-learning skills. This indicates that younger teachers with good access to ICT at the workplace have the best preconditions to develop their e-learning skills. The conclusion was confirmed when cross-tabulating the Swedish Educational Broadcasting Company survey's data about teachers' ages with their principal organizer a correlation $(p<0.001)$ is evident, indicating a higher proportion of younger teachers in independent schools: 55 percent of teachers in independent schools are under age 45 , versus 41 percent in public schools.

To comprehend the difference regarding teacher age between independent and public schools, the use of ICT in schools must be placed in a broader societal perspective. Building upon the understanding of knowledge economy, knowledge societies transform the way school organizations are understood: from public institutions to commercial enterprises, competing on the educational market for the best teachers and students. The independent schools in Sweden are direct offspring of the growing knowledge-based industry, as such they act according to the logic of the knowledge economy, i.e. as new organizations in an old system they need to promote and make them attractive, as a worthy alternative to public school. One resource that is used in this self-promoting endeavor of schools is ICT. By investing in new ICTs - more heavily than public schools (Hansson, 2009; The Swedish National Agency for Education, 2009b;) - hand in hand with ICT experienced teachers, independent schools can enhance their attractiveness and value on the educational market. If the younger teachers' greater tendency to choose independent schools as employers can be explained by independent schools' greater ICT investments remains to be investigated. It is also conceivable that other factors, such as wages and that young teachers are 
not quite as motivated by the traditional welfare state educational ideals and principles as previous Swedish teacher generations, influence their choice of principal organizer.

However, merely having access to ICT does not automatically make you good at using it. Schools need to work actively and strategically to enhance and cultivate teachers' ICT skills. This standpoint is supported by a recent study by Swedish National Agency for Education (2013), which shows that independent schools often have more comprehensive ICT strategic plans and more regular follow ups than the public schools. The report also reveals differences between access to technical support and the principals' ICT skills to lead the ICT strategic work and to develop the use of ICT in teaching.

Whether the gap between ICT-rich independent schools and ICT-poor public schools continues to grow cannot be ascertained without longitudinal studies. However, given that younger teachers are overall more likely to use ICT, and that proportionally more younger teachers are working at independent schools, which, in turn, are more likely to invest more in ICT infrastructure, ICT skilled leadership, and technical support, we can probably expect teachers already working in ICT-rich environments to further develop their ICT competence and pedagogical skills. Following the logic on which the notion of the knowledge society rests, it would be plausible to think that the identified ICT access and knowledge gap between teachers in public and independent schools will continue to grow. And an increased gap between public and independent school teachers' access to and use of ICT reflects, in all likelihood, a similar gap between pupils' access and use of ICT in public and independent schools, ultimately contributing to unequal opportunities to engage in learning activities. For example, studies points to a correlation between independent schools and pupils' results - in favor of the pupils in independent schools (Ahlin, 2003; Böhlmark \& Lindahl, 2007, 2012). Accordingly, we suggest that teachers' access to and use of ICT should be considered a complementary indicator for measuring inequity in schools, for instance to be used in the state regulation and inspection of schools.

Besides continuous investments in ICT environments in schools, we propose the need for ICT strategic plans and their follow up, promoting ICT skills among principals and administrating technical support to achieve an equal distribution of the digitalization of the school with equivalent conditions for teachers as well as for pupils, regardless of principal organizer.

\section{Acknowledgments}

We would like to thank the Swedish Educational Broadcasting Company, especially Erik Fichtelius (CEO) and Agneta Sommansson (Head of the company's strategic unit), for access to the data. We would also like to thank Sinisa Sauli at Statistics Sweden.

This article was in part made possible through funding from Riksbankens Jubileumsfond.

\section{References}

Ahlin, Å. (2003). Does school competition matter? Effects of a large-scale school choice reform on student performance. Uppsala: Department of Economics, Uppsala University. 
Bell, D. (1976). The coming of post-industrial society: A venture in social forecasting. New York: Basic Books.

Berisha-Namani, M. \& Badivuku-Pantina, M. (2009). Information society and knowledge economy, Lex et Scientia, 16(2), 555-559.

Broady, D. (ed.) (2000). The school in the 1990s: Social conditions and educational strategies [Skolan under 1990-talet: Sociala förutsättningar och utbildningsstrategier]. Report to the Final account of the Welfare committé. Uppsala: Uppsala University.

Böhlmark, A. \& Lindahl M. (2007). The impact of school choice on pupil achievement, segregation and costs: Swedish evidence. IZA Discussion Paper, no 2786. Bonn: Institute for the Study of Labor.

Böhlmark, A. \& Lindahl, M. (2012). Independent schools and long-run educational outcomes Evidence from Sweden's large-scale freedom of choice reform. Working Paper Series, no 2012:15. Uppsala: Uppsala Center for Labor Studies, Department of Economics, Uppsala University.

Cartelli, A. (2006). Teaching in a knowledge society: New skills and instruments for teachers. Hershey \& London: Information Science Publishing.

Castells, M. (2000). The rise of the network society. Oxford: Blackwell.

Castells, M. \& Cardoso, G. (2005). The network society: From knowledge to policy. Washington: Johns Hopkins Center for Transatlantic Relations.

Epstein, D., Nisbet, E. C. \& Gillespie, T. (2011). Who's responsible for the digital divide? Public perceptions and policy implications. The Information Society, 27(2), 92-104.

Erstad, O. (2006). A new direction? Digital literacy, student participation and curriculum reform in Norway. Journal of Educational Information Technology, 11, 415-429.

Government Bill (1991/92). On freedom of choice and independent schools [Om valfrihet och fristående skolor]. Stockholm: Fritzes.

Government Bill (1992/93). Freedom of choice in the school [Valfrihet i skolan]. Stockholm: Fritzes.

Hanson. M. E. (2009, April 17). Pupils in private schools get better computers [Elever på friskolor får bättre datorer]. Svenska Dagbladet. Retrieved on 10 May 2010 from http://www.svd.se/ nyheter/inrikes/elever-pa-friskolor-far-battre-datorer_2745989.svd.

Hargreaves, A. (2003). Teaching in the knowledge society: Education in the age of insecurity. New York: Teachers College Press.

Jedeskog, G. \& Nissen, J. (2004). ICT in the classroom: Is doing more important than knowing? Education and Information Technologies, 9(1), 37-45.

Johnson, L., Levine, A., Smith, R., \& Stone, S. (2010). The 2010 Horizon report. Austin, Texas: The New Media Consortium. Retrieved on 1 February 2013 from http://wp.nmc.org/ horizon2010/.

Kahin, B. \& Foray, D. (eds.) (2006). Advancing knowledge and the knowledge economy. Cambridge: MIT University Press. 
Korte, W. B. \& Hüsing, T. (2006). Benchmarking access and use of ICT in European schools 2006: Results from head teacher and a classroom teacher surveys in 27 European countries. Bonn: Empirica Gesellschaft für Kommunikations- und Technologieforschung. Retrieved on 1 February 2013 from www.empirica.biz/publikationen/documents/No08-2006_learnInd.pdf.

Knowledge Foundation (2005). ICT and student teachers: Attitudes, access and use [IT och lärarstuderande: Attityder, tillgång och användning]. Retrieved on 1 February 2013 from http://www.kks.se/om/Lists/Publikationer/Attachments/8/it-och-lararstuderande-2005publ.pdf.

Knowledge Foundation (2006). ICT in schools: Attitudes, access and use [IT i skolan: Attityder, tillgång och användning]. Retrieved on 1 October 2010 from http://www.kks.se/om/Lists/ Publikationer/Attachments/6/it_i_skolan_2006_2006_publ.pdf

Kodama, M. (2007). Project-based organization in the knowledge-based society. London: Imperial College Press.

Kofman, E. (2007). The knowledge economy, gender, and stratified migrations. Studies in Social Justice, 1(2), 123-135.

Kumar, A. (2012). Sociological theory and the knowledge society. International Journal of Human Sciences, 9(2), 764-772.

Lundström, U. \& Parding, K. (2011). Teachers' experiences with school choice: Clashing logics in the Swedish education system. Education Research International, 10 pages. Retrieved on 1 February 2012 from http://www.hindawi.com/journals/edu/2011/869852/cta/.

Machlup, F. (1962). Production and distribution of knowledge in the United States. Princeton, NJ: Princeton University Press.

OECD (2001). Understanding the digital divide. OECD Digital Economy Papers, 49. Paris: OECD. Retrieved from 10.1787/236405667766.

OECD (2007). Broadband and ICT access and use by households and individuals. OECD Digital Economy Papers, 135. Paris: OECD Publishing. Retrieved on 1 February 2012 from $10.1787 / 230666254714$.

OECD (2010). Are the new millennium learners making the grade? Technology use and educational performance in PISA 2006. Educational Research and Innovation. Paris: OECD Publishing. Retrieved on 1 February 2012 from 10.1787/9789264076044-en.

OECD (2011). PISA 2009 results: Students on line: Digital technologies and performance (volume VI). Paris: OECD Publishing. Retrieved on 1 February 2012 from 10.1787/9789264112995-en.

Persson, M. \& Thunman, E. (2010). Swedish teachers' media habits and use of the Swedish Educational Broadcasting Company. The academic year 2009/2010 [Svenska lärares mediavanor och UR-användning. Läsåret 2009/2010]. Stockholm: Swedish Educational Broadcasting Company.

Prensky, M. (2001). Digital natives, digital immigrants. On the Horizon, 9(5), 1-6.

Rahaman, M. M. (2003). Organisational knowledge creation and the commercialisation of state mail service. International Journal of Public Sector Management, 16, 373-392. 
Ramböll (2006). E-learning Nordic 2006. Copenhagen: Ramböll Management. Retrieved on 20 October 2010 from http://www.oph.fi/download/47637_eLearning_Nordic_English.pdf.

Reich, R. (1991). The work of nations: Preparing ourselves for 21st-century capitalism. New York: Knopf.

Sahlberg, P. (2006). Education reform for raising economic competitiveness. Journal of Educational Change, 7(4), 259-287.

Sahlberg, P. \& Boce, E. (2010). Are teachers teaching for a knowledge society? Teachers and Teaching: Theory and Practice, 16(1), 31-48.

Swedish Media Council (2010a). Kids \& media [Ungar \& Medier]. Retrieved on 1 February 2012 from http://www.s tatensmedierad.se/upload/Rapporter_pdf/Ungar_\&_medier_2010.pdf.

Swedish Media Council (2010b). Little kids \& media - facts about young children's use and perceptions of media [Småungar \& Medier - fakta om små barns användning och upplevelser av medier]. Retrieved on 1 February 2012 from http://www.statensmedierad. se/upload/Rapporter_pdf/Smaungar_\&_medier2010.pdf.

Swedish National Agency for Education (2007). Effective use of ICT in schools: An analysis of current research [Effektivt användande av IT i skolan: Analys av aktuell forskning]. Stockholm: Liber Distribution. Retrieved on 1 February 2012 from http://www.skolverket. se/publikationer? id=1906.

Swedish National Agency for Education (2009a). Presentation of the assignment of a follow-up of the use of ICT and ICT skills in preschool, school and adult education [Redovisning av uppdrag om uppföljning av IT-användning och IT-kompetens I förskola, skola och vuxenutbildning]. Stockholm: Swedish National Agency for Education. Retrieved on 1 February 2012 from http://www.skolverket.se/publikationer?id=2192.

Swedish National Agency for Education (2009b). Accounting for the assigment to assess organisations' and principals' developmental needs regarding the use of ICT in preschool, school and adult education, and to suggest interventions [Redovisning av uppdraget att bedöma verksamheters och huvudmäns utvecklingsbehov avseende IT-användningen inom förskola, skola och vuxenutbildning samt ge förslag på insatser]. Stockholm: Swedish National Agency for Education. Retrieved on 1 February 2012 from http://www.skolverket. se/publikationer? id=2244.

Swedish National Agency for Education (2009c). What affects the results of the Swedish elementary school? Knowledge review about the importance of different factors [Vad påverkar resultaten i svensk grundskola? Kunskapsöversikt om betydelsen av olika faktorer]. Stockholm: Swedish National Agency for Education. Retrieved on 1 February 2012 from http://www.skolverket. se/publikationer?id=2260.

Swedish National Agency for Education (2010a). Equipped to face the future? PISA 2009 on 15 year olds' reading comprehension and knowledges in mathematics and physical science [Rustad att möta framtiden? PISA 2009 om 15-åringars läsförståelse och kunskaper i matematik och naturvetenskap]. Stockholm: Swedish National Agency for Education. Retrieved on 1 February 2012 from http://www.skolverket.se/publikationer?id=2473. 
Swedish National Agency for Education (2010b). Erroneous claims about PISA. A reply to a debate article in Dagens Nyheter, published 2010-12-15 [Felaktiga påstående om PISA. Replik på debattartikel i Dagens Nyheter, publicerad 2010-12-15]. Stockholm: Swedish National Agency for Education. Retrieved on 20 October 2011 from http://www.skolverket.se/press/ debattartiklar/ felaktiga-pastaenden-om-pisa-1.147760.

Swedish National Agency for Education (2012, May 4). Presentation of the press conference on Equal education in the Swedish school system [Presentation från presskonferensen om Likvärdig utbildning i det svenska skolsystemet]. Stockholm: Swedish National Agency for Education. Retrieved on 20 October 2012 from http://www.slideshare.net/skolverket/ presentation-presskonf-likvrdig-utbildning-2012-0504.

Swedish National Agency for Education (2013). ICT usage and ICT skills in schools [It-användning och it-kompetens i skolan]. Stockholm: Swedish National Agency for Education. Retrieved on 15 May 2013 from http://www.skolverket.se/publikationer?id=3005.

Sörensen, B. H., Danielsen, O. \& Nielsen, J. (2006). Children's informal learning in the context of schools of the knowledge society. Education and Information Technologies, 12, 17-27.

Sörlin, S. \& Vessuri, H. (eds.) (2007). Knowledge society vs. knowledge economy: Knowledge, power, and politics. Gordonsville: Palgrave Macmillan.

Tichenor, P. J., Donohue, G. A. \& Olien, C. N. (1970). Mass media flow and differential growth in knowledge. Public Opinion Quarterly, 34(2), 159-170.

Trilling, B. \& Hood, P. (1999). Learning, technology, and education reform in the knowledge age or "we're wired, webbed, and windowed, now what? Educational Technology, 3(5), 5-18.

UN (2005). Understanding knowledge societies. In twenty questions with the index of knowledge societies. New York: United Nations. Retrieved on 15 May 2011 from http://www.unpan1. un.org/intradoc/groups/public/documents/un/unpan020643.pdf

UNESCO (2011). ICT in teacher education: Policy, open educational resources and partnership. Proceedings, IITE 2010. Retrieved on 10 November 2012 from http://iite.unesco.org/ publications/3214684/.

Uzunboylu, H. \& Tuncay, N. (2010). Divergence of digital world of teachers. Educational Technology \& Society, 13(1), 186-194.

Warschauer, M. (2003). Technology and social inclusion: Rethinking the digital divide. Cambridge: The MIT Press.

World Internet Institute (2009). Young Swedes and the Internet 2009 [Unga svenskar och Internet 2009]. Retrieved on 10 October 2010 from http://www.statensmedierad.se/upload/ Rapporter_pdf/Unga\%20 svenskar\%20och\%20Internet\%202009.pdf.

Correspondence: Elin Thunman, Ph.D., Senior Lecturer, Department of Sociology, Uppsala University, Uppsala, Sweden 